\title{
Phytochemical and Antioxidant Evaluation of the Flavonoids and Tannins from Synadenium grantii Hook f, (Ephorbiaceae)
}

\author{
Asmaa S. Abd Elkarim, ${ }^{1 *}$, Sahar Abdelaziz², Hany Gouda Attiaa, ${ }^{3,4}$ Hanan A.A. Taie ${ }^{5}$, Rafik Monir
}

Asmaa S. Abd Elkarim ${ }^{1, *}$, Sahar Abdelaziz ${ }^{2}$, Hany Gouda Attia ${ }^{3,4}$ Hanan A.A. Taie ${ }^{5}$, Rafik Monir ${ }^{6}$

'Chemistry of Tanning Materials and Leather Technology Department, National Research Centre, 33 El Bohouth st. (former EL Tahrir st.)-Dokki-Giza-P.0.12622, EGYPT.

2Pharmacognosy department, Faculty of Pharmacy, Zagazig University, 44519 Zagazig, EGYPT.

${ }^{3}$ Department of pharmacognosy, faculty of pharmacy, Najran University, Najran 55461, SAUDI ARABIA.

${ }^{4}$ Department of pharmacognosy, faculty of pharmacy, Kafr EL-Shiekh university, EGYPT. ${ }^{5}$ Plant Biochemistry Department, Division of Agriculture and Biological Researches, National Research Centre, 33 El-Bohouth St. (Former El-Tahrir St.), Dokki 12622, Giza, EGYPT.

${ }^{6}$ Pharmacogonosy department, Faculty of Pharmaceutical sciences and drug manufacturing, Misr University for Science and Technology, 6th October City, EGYPT.

\section{Correspondence}

\section{Asmaa S. Abd Elkarim}

Chemistry of Tanning Materials and Leather Technology Department, National Research Centre, 33 El Bohouth st. (former EL Tahrir st.)-Dokki-Giza-P.O.12622, EGYPT.

E-mail: asmaa_nrc@yahoo.com

History

- Submission Date: 29-06-2020;

- Review completed: 25-07-2020;

- Accepted Date: 03-08-2020.

DOI : 10.5530/pj.2020.12.196

Article Available online http://www.phcogj.com/v12/i6

\section{Copyright}

(c) 2020 Phcogj.Com. This is an openaccess article distributed under the terms of the Creative Commons Attribution 4.0 International license.

\section{ABSTRACT}

Background: The methanol extract (MeE) of the aerial parts from Synadenium grantii Hook $f$, (Ephorbiaceae) has more Polyphenols and used to treat several diseases. Objective: The aim of this study is isolation, purification and identification of Polyphenols that showed good antioxidant activity.

Materials and Methods: In the present study, purification of the $\mathrm{MeOH}-\mathrm{H}_{2} \mathrm{O}$ extract $(70: 30)$ from the air-dried aerial parts of $S$. grantii resulted by different chromatographic tools. The antioxidant activities were evaluated for the examined compounds by several methods using DPPH, Reducing power, ABTS and FRAP assays. Results: A total of $\mathbf{1 4}$ compounds were isolated from this plant species for the first time. The results obtained showed that all the examined compounds possess remarkable antioxidant activity through all assays especially compounds $\mathbf{2}$ and $\mathbf{4}$ where they showed the highest antioxidant activity among the other compounds and very close to the results of the standard compound BHA. Conclusion: The compounds examined have exhibited antioxidant activity with promising value as natural source antioxidant drugs.

Key words: Synadenium grantii, Ephorbiaceae, Flavonoids, Tannins, Antioxidant.

\section{INTRODUCTION}

Plants are an significant source of natural antioxidants that counter oxidative stress induced by an increase in free radicals / ROS such as superoxide $\mathrm{O} 2-$ anion, hydroxyl radical $\mathrm{HO}-$ and peroxide as well ${ }^{1}$. The phytoconstituents research of these bioactive compounds in a plant is therefore of paramount importance, resulting to further biological and pharmacological studies. This study can be presented to develop herbal medicines that require the isolation of bioactive compounds from medicinal plants ${ }^{2}$. In recent research advances around the world the properties of medicinal plants have been studied because of no side effects, safety in contrast to the synthetics that are unsafe to human and environment. As a result people are more favourable to use natural compounds obtained from plants. It is great interest for scientists to focus on the search of biologically active compounds from plants as a natural source of useful drugs against infectious diseases ${ }^{3}$. Biological studies of herbal products (active ingredient) may be due to a variety of chemical components including flavonoids, phenolics, glycosides, anthocyanins, tannins, etc. ${ }^{4}$. Natural products are considered a drug source for several years, and have been chosen to interact with biological studies as a target ${ }^{5}$. The bioactive constituents in plant Phenolic compounds (PCs) for example, flavonoids are greater antioxidant activity ${ }^{6}$. Several studies have shown that many plants are rich source of antioxidants. One of these plants is $S$. grantii (Ephorbiaceae) that a plant species which belongs to a small genus of about 15 species. Plants from this genus for example
(S. umbellatum, S. glaucescens, S.compactum, S.claycinum ) have different biological activities as anti-ulcer activity ${ }^{7}$, antiasthmatic effect ${ }^{8}$, antitumoral and anti-angiogenic effects ${ }^{9}$, antinoceptive anti-inflammatory, anti-plasmodial activity ${ }^{10}$. The aim of this work is to study the antioxidant activity of the isolated pure compounds from $\mathrm{MeOH}-\mathrm{H}_{2} \mathrm{O}$ extract (70:30) of $S$. grantii for the first time.

\section{MATERIALS AND METHODS}

\section{General methods}

NMR spectra were recorded at $400 \mathrm{MHz}$ for NMR and $100 \mathrm{MHz}$ for ${ }^{13} \mathrm{C}$ NMR on Bruker AMX400, Avance 400, and Avance 300 spectrometers (Bruker, Rheinstetten, Germany) with standard pulse sequences operating at $400 \mathrm{MHz}$ in ${ }^{1} \mathrm{H}$ NMR and $100, \mathrm{MHz}$ in ${ }^{13} \mathrm{CNMR}$.chemical shifts was expressed in $\delta$ values (ppm) using DMSO as the internal standard. QTOF-HR-TOF4500scan (HPLC system was coupled to quadruple time-of-flight mass spectrometer), Column chromatography (CC) was carried out on Polyamide 6S (Riedel-DeHaen, Hannover, Germany) and sephadex LH-20 (Fluka, Pharmazia, Uppsala, Sweden).

\section{Plant material}

A sample of S. grantii (aerial parts) was collected from National Research Centre (NRC) garden, Egypt in 2017 (flowering stage). The plant species was identified by Dr. M. EL-Gibaly, Lectuer of Taxonomy and Consultant for Central Administration of Plantation and Environment. Avoucher sample (No: A79.) was deposited at chemistry of tanning 
materials and leather technology department, (NRC), Dokki, Cairo, Egypt.

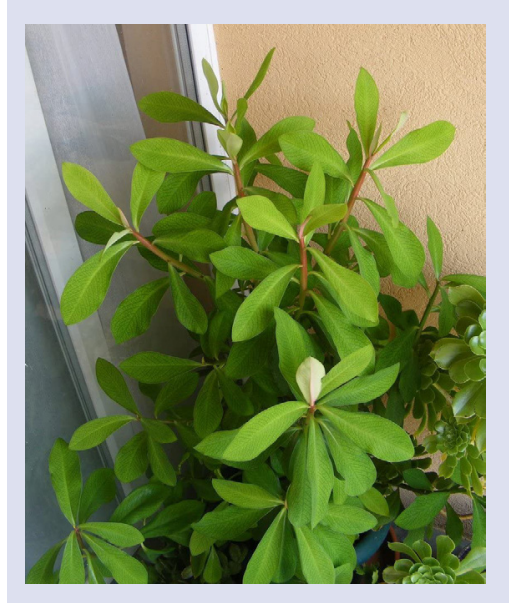

\section{Extraction and isolation}

The aerial parts of $S$. grantii $(1.75 \mathrm{~kg})$ were crushed and extracted by macération with $70 \%$ aqueous $\mathrm{CH}_{3} \mathrm{OH}$, the methanol water extract was evaporated under reduced pressure and lyophilized (250gm). A sample $(150 \mathrm{gm})$ of the dry extract was fractionated by chromatography on polyamide $6 \mathrm{~S}$ column $(60 \mathrm{x} 4 \mathrm{~cm})$. The column was eluted with $\mathrm{H}_{2} \mathrm{O}$ and $\mathrm{H}_{2} \mathrm{O}-\mathrm{MeOH}$ step gradient by decreasing polarities at a flow rate $1 \mathrm{ml} /$ minute was then carried out. The bands migrated along the column were traced under UV light during elution to note their characteristics and to control the fractionation process as well. The obtained fractions (1litre, each) were subjected to paper chromatography using BAW and $15 \% \mathrm{AcOH} / \mathrm{H} 2 \mathrm{O}$ as a developing solvents, and the similar fractions were collected together to give four major fractions (I-IV). The subfractions were then subjected to different chromatographic techniques including, cellulose and repeated sephadex LH-20 column using eluents of different polarities. This led to the isolation and purification of six flavonoid compounds (1-6). Some sub fractions precipitated with diethyl ether, then subjected to sephadex LH-20 column with absolute ethanol to give compounds (7-14).

Separation of fraction I (8g) on sephadex column LH-20 CC with saturated $\mathrm{n}-\mathrm{Bu}-\mathrm{H}_{2} \mathrm{O}$ gave three sub-fractions, then the first and third sub-fractions were purified on sephadex LH-20CC using EtOH-H2O $(1: 1)$ as solvent system and gave a pure samples of $\mathbf{1}(28 \mathrm{mg})$ and $\mathbf{2}$ (35 mg). The second sub-fraction was subjected to sephadex LH-20CC with EtOH-H2O (30:70) as an eluent to give two major compounds which were further purified on sephadex $\mathrm{CC}$ using $\mathrm{MeOH}$ (HPLC) as solvent to give pure samples of $3(30 \mathrm{mg})$ and $\mathbf{4}(35 \mathrm{mg})$.

Fraction II (6.5 gm) was chromatographed on sephadex LH-20CC and eluted with EtOH for further times to afford pure compounds of 5 (25 $\mathrm{mg}$ ) and 6 (18 $\mathrm{mg})$

Fraction III (13 gm) has been separated on cellulose column chromatography with n-BIW as eluent to give six sub-fractions. Four of them subjected to sephadex LH-20CC with absolute EtOH to give four pure samples of $\mathbf{7}(20 \mathrm{mg}), \mathbf{8}(22 \mathrm{mg})$ and $\mathbf{9}(18 \mathrm{mg})$. The last two subfracions were purified by precipitation with diethyl ether the filtrate and precipitate were applied on sephadex CC with HPLC methanol to afford pure compounds of $\mathbf{1 0}(20 \mathrm{mg}), \mathbf{1 1}(16 \mathrm{mg})$ and $\mathbf{1 2}(18 \mathrm{mg})$.

Fraction IV (3.5 gm) was fractionated by the same way of fraction I to give two pure samples $13(1.5 \mathrm{gm})$ and $\mathbf{1 4}(1.1 \mathrm{gm})$ which identified by compared with authentic samples on paper chromatography (PC).

Structure elucidation established by using NMR data ${ }^{1} \mathrm{H}$ NMR (400MHz, DMSO- $\mathrm{d}_{6}$ ) and ${ }^{13} \mathrm{C}$ NMR $\left(100 \mathrm{MHz}, \mathrm{DMSO}-\mathrm{d}_{6}\right)$.

\section{Quercetin3-O- $\beta$-D-glucopyranoside (1)}

Yellow amorphous powder, UV $\lambda_{\max }(\mathrm{MeOH}) \mathrm{nm}: 351,253 ;{ }^{1} \mathrm{H}$ NMR $\left(400 \mathrm{MHz}, \mathrm{DMSO}-\mathrm{d}_{6}\right) \delta(\mathrm{ppm}): 7.67\left(1 \mathrm{H}, \mathrm{dd}, J=8.6,2 \mathrm{~Hz}, \mathrm{H}-6^{\prime}\right) ; 7.36$ $\left(1 \mathrm{H}, \mathrm{d}, J=2 \mathrm{~Hz}, \mathrm{H}-2^{\prime}\right), 6.87\left(1 \mathrm{H}, \mathrm{d}, J=8.6 \mathrm{~Hz}, \mathrm{H}-5^{\prime}\right), 6.41(1 \mathrm{H}, \mathrm{d}, J=$ $1.8 \mathrm{~Hz}, \mathrm{H}-8), 6.21(1 \mathrm{H}, \mathrm{d}, J=1.8 \mathrm{~Hz}, \mathrm{H}-6), 5.34(1 \mathrm{H}, \mathrm{d}, J=8 \mathrm{~Hz}, \mathrm{H}-1 ")$, $5.28(1 \mathrm{H}, \mathrm{m}, \mathrm{H}-2 "), 3.66(1 \mathrm{H}, \mathrm{dd}, \mathrm{J}=12.5 \mathrm{~Hz}, \mathrm{H}-6 " \mathrm{a}), 3.42(1 \mathrm{H}, \mathrm{br} \mathrm{d}, \mathrm{J}=$ $11.5 \mathrm{~Hz}, \mathrm{H}-6 " \mathrm{~b}), 3.23$ (1H, t, J = $8.4 \mathrm{~Hz}, \mathrm{H}-3 "), 2.98$ (1H, m, H-4"), 2.95 $(1 \mathrm{H}, \mathrm{m}, \mathrm{H}-5 ") .{ }^{13} \mathrm{C}$ NMR $\left(100 \mathrm{MHz}, \mathrm{DMSO}-\mathrm{d}_{6}\right) \delta(\mathrm{ppm}): 176.90(\mathrm{C}-4)$, 165.80 (C-7), 162.30 (C-5), 156.60 (C-2), 156.50 (C-9), 147.80 (C-4'), 144.60 (C-3'), 134.30 (C-3), 122.00 (C-1'), 121.50 (C-6'), 116.00 (C-2'), 115.70 (C-5'), 104.00 (C-10), 98.00 (C-6), 93.68 (C-8), 102.00 (C-1"), 76.70 (C-5"), 73.65 (C-3"), 71.60 (C-2"), 71.10 (C-4"), 61.85 (C-6").

\section{(Quercitrin ) quercetin3-O-a-L-rhamnoside (2)}

Yellow amorphous powder, UV $\lambda_{\max }(\mathrm{MeOH}) \mathrm{nm}: 344,253 ;{ }^{1} \mathrm{H}$ NMR $\left(400 \mathrm{MHZ}, \mathrm{DMSO}-\mathrm{d}_{6}\right) \delta(\mathrm{ppm}): 7.77\left(1 \mathrm{H}, \mathrm{dd}, J=8.5,2 \mathrm{~Hz}, \mathrm{H}-6^{\prime}\right), 7.29$ $\left(1 \mathrm{H}, \mathrm{d}, J=2 \mathrm{~Hz}, \mathrm{H}-2^{\prime}\right), 6.93\left(1 \mathrm{H}, \mathrm{d}, J=8.6 \mathrm{~Hz}, \mathrm{H}-5^{\prime}\right), 6.39(1 \mathrm{H}, \mathrm{d}, J=2$ $\mathrm{Hz}, \mathrm{H}-8), 6.21(1 \mathrm{H}, \mathrm{d}, J=2 \mathrm{~Hz}, \mathrm{H}-6), 5.29$ (1H, br $s, \mathrm{H}-1 "), 5.26(1 \mathrm{H}, \mathrm{m}$, H-2"), 3.98 (1H, br d, H-3"), 3.529 (1H, t-like, J=8.8Hz, H-4") ), 3.23 ( $1 \mathrm{H}, \mathrm{dq}$ (sextet) , J = 9.2, $6.4 \mathrm{~Hz}, \mathrm{H}-5 "), 1.07$ ( $3 \mathrm{H}, \boldsymbol{s}, \mathrm{CH}_{3}$ of rhamnose), ${ }^{13} \mathrm{C}$ NMR (100MHz, DMSO-d $) \delta(\mathrm{ppm}): 177.50$ (C-4), $165.34(\mathrm{C}-7)$, 162.34 (C-5), 156.22 (C-2), 156.99 (C-9), 147.60 (C-4'), 144.11 (C-3'), 134.27 (C-3), 121.18 (C-1'), 120.91 (C-6'), 115.81 (C-5'), 115.61 (C-2'), 98.90 (C-6), 94.39 (C-8), 103.23 (C-10), 101.87 (C-1"), 71.25 (C-5"),

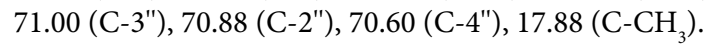

\section{Quercetin3-O- $\beta$-D-galactopyranoside (3)}

Yellow amorphous powder, UV $\lambda_{\max }(\mathrm{MeOH}) \mathrm{nm}: 352,256 ;{ }^{1} \mathrm{H}$ NMR (400MHZ, DMSO-d $\left.{ }_{6}\right) \delta(\mathrm{ppm}): 7.68\left(1 \mathrm{H}, \mathrm{dd}, J=8.5,2 \mathrm{~Hz}, \mathrm{H}-6^{\prime}\right), 7.57$ $\left(1 \mathrm{H}, \mathrm{d}, J=2 \mathrm{~Hz}, \mathrm{H}-2^{\prime}\right), 6.86\left(1 \mathrm{H}, \mathrm{d}, J=8.6 \mathrm{~Hz}, \mathrm{H}-5^{\prime}\right), 6.41(1 \mathrm{H}, \mathrm{d}, J=2$ $\mathrm{Hz}, \mathrm{H}-8), 6.20(1 \mathrm{H}, \mathrm{d}, J=2 \mathrm{~Hz}, \mathrm{H}-6), 5.45(1 \mathrm{H}, \mathrm{d}, J=7.6 \mathrm{~Hz}, \mathrm{H}-1 "), 5.39$ $(1 \mathrm{H}, \mathrm{dd}, \mathrm{J}=10.8 \mathrm{~Hz}, \mathrm{H}-2 "), 3.65$ ( $1 \mathrm{H}, \mathrm{m}, \mathrm{H}-6 \mathrm{a}), 3.59$ (1H, dd, J = 6 Hz, H-3"), 3.44 (1H, br s, H-4"), $3.32(1 \mathrm{H}, \mathrm{m}, \mathrm{H}-5 "), 3.24(1 \mathrm{H}, \mathrm{dd}, \mathrm{J}=13 \mathrm{~Hz}$, $\mathrm{H}-6 " \mathrm{~b}),{ }^{13} \mathrm{C}\left(100 \mathrm{MHz}, \mathrm{DMSO}-\mathrm{d}_{6}\right) \delta(\mathrm{ppm}): 176.20$ (C-4 ), $164.20(\mathrm{C}-7)$, 163.90 (C-5 ), 155.90 (C-2), 155.5 (C-9), 146.90 (C-4'), 144.61 (C-3'), 134.55 (C-3), 122.73 (C-1'), 122.30 (C-6'), 115.96 (C-2'), 115.60 (C-5'), 103.91 (C-10), 102.03 (C-1"), 98.70 (C-6), 94.65 (C-8), 76.90 (C-5"), 75.83 (C-3"), 74.65 (C-2"), 70.55 (C-4"), 61.79 (C-6").

\section{Kaempferol3-O- $\beta$-D-galactopyranoside (4)}

Yellow amorphous powder, UV $\lambda_{\max }(\mathrm{MeOH}) \mathrm{nm}: 346,266{ }^{1} \mathrm{H}$ NMR (400MHZ, DMSO-d $) \delta(\mathrm{ppm}): 8.05\left(2 \mathrm{H}, \mathrm{d}, J=9.6 \mathrm{~Hz}, \mathrm{H} 2^{\prime} / 6^{\prime}\right), 6.90(2 \mathrm{H}$, $\left.\mathrm{d}, J=9.6 \mathrm{~Hz}, \mathrm{H} 3^{\prime} / 5^{\prime}\right), 6.44(1 \mathrm{H}, \mathrm{d}, J=2 \mathrm{~Hz}, \mathrm{H}-6), 6.22(1 \mathrm{H}, \mathrm{d}, J=2 \mathrm{~Hz}$, H-8), 5.37 (1H, d, $\left.J=7.5 \mathrm{~Hz}, \mathrm{H}-1^{\prime \prime}\right), 5.37(1 \mathrm{H}, \mathrm{m}, \mathrm{H}-2 "), 3.35(1 \mathrm{H}, \mathrm{dd}$, $\mathrm{J}=11.6,2.5 \mathrm{~Hz}, \mathrm{H}-6$ "a), 3.58 (1H, dd, J=8.8, 3.0 Hz, H-3"), 3.47 (1H, br s, H-4"), 3.21 (1H, dd, J = $8.8 \mathrm{~Hz}, \mathrm{H}-5 "), 3.15$ (1H, dd, J=13, $6 \mathrm{~Hz}, \mathrm{H}-6 " \mathrm{~b})$, ${ }^{13} \mathrm{C}(100 \mathrm{MHz}$, DMSO-d $)$ $) \delta(\mathrm{ppm}): 176.81$ (C-4 ), 165.02 (C-7), 163.73 (C-5 ), 155.30 (C-2), 155.5 (C-9), 147.90 (C-4'), 144.61 (C-3'), 133.68 (C-3), 122.56 (C-1'), 122.31 (C-6'), 115.96 (C-2'), 115.20 (C-5'), 103.91 (C-10), 101.82 (C-1"), 98.70 (C-6), 94.55 (C-8), 77.10 (C-5"), 76.60 (C3"), 74.75 (C-2"), 70.94 (C-4"), 62.00 (C-6").

\section{Kaempferol3-O- a-L-rhamnoside (5)}

Yellow amorphous powder, UV $\lambda_{\max }(\mathrm{MeOH}) \mathrm{nm}: 346,266{ }^{1} \mathrm{H}$ NMR $\left(400 \mathrm{MHZ}, \mathrm{DMSO}-\mathrm{d}_{6}\right) \delta(\mathrm{ppm}): 7.76\left(2 \mathrm{H}, \mathrm{d}, J=8.8 \mathrm{~Hz}, \mathrm{H} 2^{\prime} / 6^{\prime}\right), 6.93$ $\left(2 \mathrm{H}, \mathrm{d}, J=8.8 \mathrm{~Hz}, \mathrm{H}^{\prime} / 5^{\prime}\right), 6.41(1 \mathrm{H}, \mathrm{d}, J=2 \mathrm{~Hz}, \mathrm{H}-6), 6.21(1 \mathrm{H}, \mathrm{d}, J=2$ $\mathrm{Hz}, \mathrm{H}-8), 5.30$ (1H, s, J=1.5, H-1"), 3.99 (1H, br $s, \mathrm{H}-2 "), 3.54(1 \mathrm{H}, \mathrm{dd}$, $\mathrm{J}=9.5,3.4 \mathrm{~Hz}, \mathrm{H}-3 "), 3.48$ (1H, m, H-4"), 3.17 (1H, dq (sextet), J=9.5, 6 $\mathrm{Hz}, \mathrm{H}-5 "), 1.18$ ( (3H, s, $\mathrm{CH}_{3}$ of rhamnose), ${ }^{13} \mathrm{C}\left(100 \mathrm{MHz}, \mathrm{DMSO}-\mathrm{d}_{6}\right)$ $\delta(\mathrm{ppm}): 178.15$ (C-4 ), 164.71 (C-7), 161.70 (C-5 ), 160.45 (C-2), 157.73 (C-9), 156.95 (C-4'), 134.63 (C-3), 131.05(C-3'/5'), , 120.95 (C-1'), 115.78 (C-2'/6'), 104.56 (C-10), 102.19 (C-1"), 99.21 (C-6), 94.24 (C- 
8), 71.56 (C-5"), 71.06 (C-3"), 70.78 (C-2"), $70.51(\mathrm{C}-4 "), 17.86\left(\mathrm{CH}_{3}\right.$ of rhamnose).

\section{Kaempferol aglycone (6)}

Yellow amorphous powder, UV $\lambda_{\max }(\mathrm{MeOH}) \mathrm{nm}: 366,266{ }^{1} \mathrm{H}$ NMR (400MHZ, DMSO- $\left.\mathrm{d}_{6}\right) \delta(\mathrm{ppm}): 8.07\left(2 \mathrm{H}, \mathrm{d}, J=8.8 \mathrm{~Hz}, \mathrm{H} 2^{\prime} / 6^{\prime}\right), 6.94$ $\left(2 \mathrm{H}, \mathrm{d}, J=8.8 \mathrm{~Hz}, \mathrm{H}^{\prime} / 5^{\prime}\right), 6.44(1 \mathrm{H}, \mathrm{d}, J=2 \mathrm{~Hz}, \mathrm{H}-6), 6.18(1 \mathrm{H}, \mathrm{d}, J=2$ $\mathrm{Hz}, \mathrm{H}-8)$

\section{Ellagic acid (7)}

White amorphous powder, UV $\lambda_{\max }(\mathrm{MeOH}) \mathrm{nm}: 364,255$ characteristic for ellagic acid (Tanaka et al., 1986). ${ }^{1} \mathrm{H}$ NMR(400MHZ, DMSO- $\mathrm{d}_{6}$ ) $\delta$ (ppm): 7.49(2H, s, H-5/5').

\section{4, 4'-di-O methyl ellagic acid (8)}

Yellow powder, UV $\lambda_{\max }(\mathrm{MeOH}) \mathrm{nm}: 375,247{ }^{1} \mathrm{H}$ NMR (400MHZ, DMSO-d $\left.{ }_{6}\right) \delta(\mathrm{ppm}): 7.69\left(2 \mathrm{H}, s, \mathrm{H}-5 / 5^{\prime}\right), 3.98\left(6 \mathrm{H}, s, 2 \mathrm{OCH}_{3}\right), \mathrm{LC}-\mathrm{Q} /$ TOF - MS ${ }^{2} \mathrm{~m} / \mathrm{z}: 330.97297[\mathrm{M}+\mathrm{H}]^{+}$

\section{3, 3'-di-O-methyl ellagic acid-4'-O-a-L-rhamnoside (9)}

Brownish yellow powder ${ }^{1} \mathrm{H}$ NMR (400MHZ, DMSO-d $\mathrm{d}_{6} \delta(\mathrm{ppm}): 7.69$ $\left(1 \mathrm{H}, s, \mathrm{H}-5^{\prime}\right), 7.43(1 \mathrm{H}, s, \mathrm{H}-5), 5.52(1 \mathrm{H}, s, \mathrm{H}-1 "), 1.81\left(3 \mathrm{H}, s, \mathrm{CH}_{3}\right.$ of rhamnose)

\section{3, 3', 4'- tri-O-methyl ellagic acid (10)}

Yellow powder, UV $\lambda_{\text {max }}(\mathrm{MeOH}) \mathrm{nm}: 370,249,{ }^{1} \mathrm{H}$ NMR $(400 \mathrm{MHZ}$, DMSO-d $\left._{6}\right) \delta(\mathrm{ppm}): 7.59,7.48(2 \mathrm{H}, s, \mathrm{H}-5,5), 4.01,4.02,3.98(9 \mathrm{H}, s$, $\left.3 \mathrm{OCH}_{3}\right)$.

\section{3, 3'-di-O-methyl ellagic acid (11)}

Yellow powder, UV $\lambda_{\text {max }}(\mathrm{MeOH}) \mathrm{nm}: 375,247^{1} \mathrm{H}$ NMR(400MHZ, DMSO-d $\left.{ }_{6}\right) \delta$ (ppm): $7.53\left(2 \mathrm{H}, s, \mathrm{H}-5 / 5^{\prime}\right), 4.00,3.98,\left(6 \mathrm{H}, s, 2 \mathrm{OCH}_{3}\right)$.

\section{3, 3', 4, 4'-tetra -O- methyl ellagic acid (12)}

Yellow powder ${ }^{1} \mathrm{H}$ NMR (400MHZ, DMSO-d $) \delta(\mathrm{ppm}): 7.74(1 \mathrm{H}, s$, $\left.\mathrm{H}-5 / 5^{\prime}\right), 4.08,4.06,4.12,3.99\left(12 \mathrm{H}, s, 4 \mathrm{OCH}_{3}\right)$

3, 4, 5-trihydroxy benzoic acid (gallic acid). (13) and methyl gallate (14)

$\mathrm{UV} \lambda_{\max }(\mathrm{MeOH}) \mathrm{nm}: 272$ characteristic for phenolic acids, were proved by co chromatography with authentic samples

\section{Quantification of total phenolic content (TPC)}

TPC was carried out using the Folin-Ciocalteu colorimetric method described by (Saboo et al 2010). Five mgs of $\mathrm{MeOH}$ extract dissolved in $5 \mathrm{ml}$ of $50 \% \mathrm{MeOH}$ to prepare a solution of final concentration, $1 \mathrm{mg} /$ $\mathrm{ml}$. An aliquot $(2 \mathrm{ml})$ of the extract and standard solution of gallic acid $(8-100 \mu \mathrm{g} / \mathrm{ml})$ was added to $25 \mathrm{ml}$ volumetric flask containing $1.5 \mathrm{ml}$ of Folin-Ciocalteureagent and $4 \mathrm{ml}$ of $20 \% \mathrm{Na}_{2} \mathrm{CO}_{3}$ solution, then the solution was diluted to $25 \mathrm{ml}$ with distilled water. The absorbance was measured, after $30 \mathrm{~min}$ at $765 \mathrm{~nm}$ using spectrophotometer, against a blank prepared at the same time using $2 \mathrm{ml}$ of distilled $\mathrm{H}_{2} \mathrm{O}$ instead of the standard solution. All concentrations were carried out in triplicate. (TPC) were expressed as gallic acid equivalent (GAE).

\section{Quantification of total flavonoid content (TFC)}

TFC of plant extract was determined according to Saboo S et al. 2010 20. $10 \mathrm{mgs}$ of the extract were dissolved in $10 \mathrm{ml}$ of $70 \% \mathrm{MeOH}$ to prepare final concentration $1 \mathrm{mg} / \mathrm{ml}$. An aliquot $(0.5 \mathrm{ml})$ of the extract and standard solution of quercetin $(10-100 \mu \mathrm{g} / \mathrm{ml})$ was added to $5 \mathrm{ml}$ volumetric flask containing $1.5 \mathrm{ml}$ of $\mathrm{MeOH}, 0.1 \mathrm{ml}$ of $10 \% \mathrm{AlCl}_{3}, 0.1$ $\mathrm{ml}$ of $1 \mathrm{M}$ potassium acetate aqueous solution and $2.8 \mathrm{ml}$ of distilled $\mathrm{H}_{2} \mathrm{O}$. The solution was mixed well and the absorbance was measured spectrophotometrically at $415 \mathrm{~nm}$ against blank. Each measurement was performed in triplicate. (TFC) was expressed as quercetin equivalent (QE).

\section{Investigation of antioxidant activity}

\section{Antioxidant activity (DPPH Assay)}

The free radical scavenging activity using the 1.1-diphenyl-2-picrylhydrazil (DPPH) reagent was determined according to BrandWilliams ${ }^{21}$. The isolated compounds (1-9) were dissolved in $85 \%$ methanol: water. To $0.5 \mathrm{ml}$ of each, $1.0 \mathrm{ml}$ of freshly prepared methanolic DPPH solution $(20 \mu \mathrm{g} / \mathrm{ml}-1)$ was added and stirred. The discoloration processes was recorded after $5 \mathrm{~min}$ of reaction at $517 \mathrm{~nm}$ and compared with a blank control.

Antioxidant activity $=[($ control absorbance - sample absorbance $) /$ control

absorbance] $\times 100 \%$

In this test, data can only be compared when obtained under identical settings.

\section{Reducing power Assay (RPA)}

The reducing power of the examined compounds was determined according to the method of Oyaizu $1986{ }^{22} .0 .5 \mathrm{ml}$ of each isolated compound were added to Phosphate buffer $(2.5 \mathrm{ml}, 0.2 \mathrm{M}, \mathrm{pH} 6.6)$ and $1 \%$ potassium ferricyanide $(2.5 \mathrm{ml})$. The mixture was incubated at $50^{\circ} \mathrm{C}$ for $20 \mathrm{~min}$. Aliquots of trichloroacetic acid $(2.5 \mathrm{ml}, 10 \%)$ were added to the mixture, which was then centrifuged at $1000 \mathrm{rpm}$ for $10 \mathrm{~min}$. The upper layer of solution $(2.5 \mathrm{ml})$ was mixed with distilled water $(2.5 \mathrm{ml})$ and a freshly prepared $\mathrm{FeCl}_{3}$ solution $(0.5 \mathrm{ml}, 0.1 \%)$. The absorbance was measured at $700 \mathrm{~nm}$. Increased absorbance of their reaction mixture indicated increased reducing power.

\section{ABTS radical scavenging assay}

ABTS assay was carried out using the method of Re et al. ${ }^{23}$. The stock solutions included $7 \mathrm{mM}$ ABTS solution and $2.4 \mathrm{mM}$ potassium persulfate solution. The working solution was then prepared by mixing the two stock solutions in equal quantities and allowing them to react for $12 \mathrm{~h}$ at room temperature in the dark. The solution was then diluted by mixing $1 \mathrm{ml}$ ABTS ${ }^{+}$Solution with $60 \mathrm{ml}$ methanol to obtain an absorbance of $0.706 \pm 0.001$ units at $734 \mathrm{~nm}$ using the spectrophotometer. ABTS ${ }^{+}$Solution was freshly prepared for each assay. The isolated compounds were allowed to react with $3 \mathrm{ml}$ of the ABTS ${ }^{+}$Solution and the absorbance were taken at $734 \mathrm{~nm}$ after 7 min using the spectrophotometer. The ABTS ${ }^{+}$scavenging capacity of different concentrations percentage inhibition calculated as ABTS radical scavenging activity using the following equation.

$(\%)=$ Abs.control - Abs.sample) $] /($ Abs.control $)] \times 100$

Where Abs. control is the absorbance of ABTS radical + methanol; Abs. sample is the absorbance of ABTS radical + sample extract. Each of the above assays was carried out in triplicate.

This test does not distinguish between the kinetics of radical trapping and stoichiometry.

\section{Ferric reducing antioxidant power assay (FRAP)}

The FRAP assay was done according to Benzie and Strain ${ }^{24}$ with some modifications. The stock solutions included $300 \mathrm{mM}$ acetate buffer, pH 3.6, $10 \mathrm{mM}$ TPTZ (2, 4, 6-tripyridyl-s-triazine) solution in $40 \mathrm{~m}$ $\mathrm{MHCl}$, and $20 \mathrm{mM} \mathrm{FeCl}_{3} \cdot 6 \mathrm{H} 2 \mathrm{O}$ solution. The fresh working solution 
was prepared by mixing $25 \mathrm{ml}$ acetate buffer, $2.5 \mathrm{ml} \mathrm{TPTZ}$ solution, and $2.5 \mathrm{ml} \mathrm{FeCl}{ }_{3} \cdot 6 \mathrm{H} 2 \mathrm{O}$ solution and then warmed at $37{ }^{\circ} \mathrm{C}$ before using. Compounds (1-9) were allowed to react with $2850 \mu \mathrm{l}$ of the FRAP solution for $30 \mathrm{~min}$ in the dark condition. Readings of the colored product [ferrous tripyridyltriazine complex] were then taken at $593 \mathrm{~nm}$. Results are expressed in $\mu$ molTrolox / g dry matter. Additional dilution was needed if the FRAP value measured was over the linear range of the standard curve. This method essentially provides the stoichiometry of antioxidants.

\section{RESULTS AND DISCUSSION}

\section{Flavonoids isolated from $70 \%\left(\mathrm{CH}_{3} \mathrm{OH} / \mathrm{H}_{2} \mathrm{O}\right)$ extract}

The purification of the aerial parts extract from S. grantii afforded $\mathbf{1 4}$ known compounds were separated for the first time by different chromatographic technique, their structures established based on NMR spectroscopic data and by comparing them to those reported in the literature (Figure 1). Compounds (1-6) were glycosides of flavonoids<smiles>O=c1c(OC2OC(O)C(O)C(O)CC(O)C2O)c(-c2ccc(O)c(O)c2)oc2cc(O)cc(O)c12</smiles>

1<smiles>O=c1c(OC2OC(O)C(O)C(O)CC(O)C2O)c(-c2ccc(O)cc2)oc2cc(O)cc(O)c12</smiles><smiles>O=c1oc2c(O)c(O)cc3c(=O)oc4c(O)c(O)cc1c4c23</smiles>

7<smiles>COc1cc2c(=O)oc3c(O)c(O)c(OC)c4oc(=O)c(c1)c2c34</smiles>

10<smiles>O=C(O)c1cc(O)c(O)c(O)c1</smiles>

13

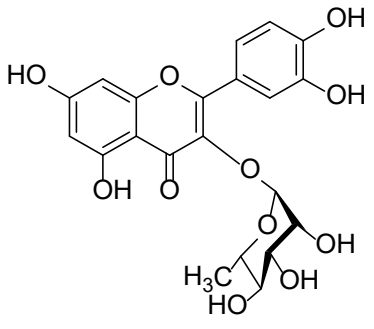

2

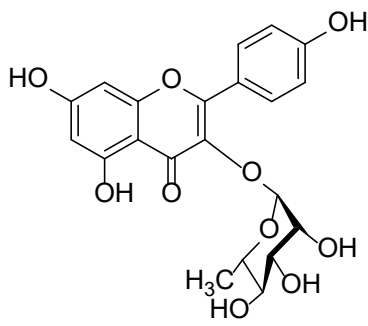

5<smiles>COc1cc2c(=O)oc3c(O)c(OC)cc4c(=O)oc(c1O)c2c34</smiles>

8<smiles>COc1c(O)cc2c(=O)oc3c(OC)c(O)cc4c(=O)oc1c2c34</smiles>

11<smiles>COC(=O)c1cc(O)c(O)c(O)c1</smiles>

14<smiles>O=c1c(OC2OC(O)C(O)C(O)C(O)C2O)c(-c2ccc(O)c(O)c2)oc2cc(O)cc(O)c12</smiles>

3<smiles>O=c1c(O)c(-c2ccc(O)cc2)oc2cc(O)cc(O)c12</smiles><smiles>COc1c(O)cc2c(=O)oc3c(OC)c(OC4O[C@H](C)[C@H](O)[C@H](O)[C@H]4O)cc4c(=O)oc1c2c34</smiles>

9<smiles>COc1cc2oc(=O)c3cc(OC)c(OC)c4oc(=O)c(c1)c2c43</smiles>

12

Figure 1: Chemical structure of isolated compounds from S. grantii. 
and aglycon, obtained as yellow solid powder, appear as dark purple spot under UV light on PC, changed to bright yellow colour and green fluorescence when exposed to ammonia vapour, after spraying with aluminium chloride.

${ }^{1} \mathrm{H}$ NMR spectrum of compound 1 showed in its aromatic region an ABX-spin coupling system, each of one proton, at $\delta p p m 7.67,7.36$ and 6.87 assignable to $\mathrm{H}-6$ ', 2' and 5', respectively. In addition, an AM-spin coupling system described in the form of two meta coupled protons at $6.41,6.21$ for $\mathrm{H}-8$ and 6 , respectively. Thus, the aglycone moiety was confirmed as a quercetin 3-O-substituted. In the aliphatic region one anomeric proton with large $J$ value was assigned at $5.34(\mathrm{~d}, J=8 \mathrm{~Hz})$ for $\beta$-configuratioin and the appearance of $\mathrm{H}-3 "$ at $3.23(1 \mathrm{H}, \mathrm{t}, J=8.4 \mathrm{~Hz}$, $\mathrm{H}-3 ")$ established compound $\mathbf{1}$ as quercetin3-O- $\beta$-D-glucopyranoside.

Compounds 2, 3 were very similar to $\mathbf{1}$. The difference between them was in the aliphatic region (sugar moiety). In compound 2 two singlet signals appeared at $\delta$ ppm 5.29 and 1.07 assignable for the anomeric and methyl rhamnose, revealed rhamnose sugar with $\alpha$-linkage. Compound 2 was confirmed to be quercetin $3-O-\alpha-\mathrm{L}$-rhamnoside. In compound 3 the appearance of $\mathrm{H}-3$ ", $J=6 \mathrm{~Hz}$ and $\mathrm{H}-4$ " as br $s$ differentiated the glycoside moiety as galactoside rather than glucoside $(J=9.5-10 \mathrm{~Hz})$, so compound 3 was identified as quercetin $3-O-\beta-D$-galactopyranoside.

${ }^{1} \mathrm{H}$ NMR spectrum of compound $\mathbf{4}$ showed in its aromatic region an $\mathrm{A}_{2} \mathrm{X}_{2}$-spin coupling system as two $o$-doublets, $(J=9.6 \mathrm{~Hz})$, each of two protons, at $\delta 8.05$ and 6.90 assignable to $\mathrm{H}-2^{\prime} / 6^{\prime}$ and $\mathrm{H}^{-} 3^{\prime} / 5^{\prime}$, respectively. In addition, an AM-spin coupling system described in the form of two $m$-coupled protons $(J=2 \mathrm{~Hz})$, at 6.44 and 6.22 for $\mathrm{H}-8$ and $\mathrm{H}-6$, respectively. Thus, the glycone moiety was confirmed as a kaempferol 3-O-substituted. In the aliphatic region the anomeric proton was assigned at $5.37(\mathrm{~d}, J=7.5 \mathrm{~Hz})$ exactly the same pattern in previous mono glycoside. Accordingly, compound $\mathbf{4}$ was finally identified as Kaempferol3-O- $\beta$-D-glucoside.

Compound 5 has the same chemical structure of $\mathbf{4}$, but its aliphatic region showed signal at $\delta \mathrm{ppm} 5.30 \mathrm{~s}, J=1.5$ was attributed to $\alpha$-anomeric proton and a singlet at 1.18 for the methyl rhamnose protons, indicating presence of rhamnosyl moiety, and confirmed compound 5 to be Kaempferol3-O- $\alpha$-L-rhamnoside. The disappearance of the anomeric in the aliphatic region exhibited that compound $\mathbf{6}$ is aglycone not glycoside and identified as Kaempferol ${ }^{11}$.

\section{Tannins isolated from methanol water extract}

Six ellagic acid derivatives were separated. Compound 7 obtained as white amorphous powder that displayed shiny buff fluorescence spot on PC under UV light, changed to dull yellow fluorescence with ammonia vapours. Spraying with $\mathrm{FeCl} 3$ gave blue colour indicating its phenolic nature. The UV spectral data exhibited two absorption bands ( $\lambda \max 364$, 255) characteristic for ellagic acid. ${ }^{1} \mathrm{H}-\mathrm{NMR}$ spectrum showed a singlet signal at $\delta \mathrm{ppm} 7.49$ integrated for two equivalent protons in aromatic region assigned for $\mathrm{H}-5$ and $\mathrm{H}-5^{\prime}$, so the compound 7 elucidated as ellagic acid ${ }^{12}$.

Compound 8, isolated as yellow powder exhibited dark violet fluorescence under short and long UV light turned greenish-yellow fluorescence with $\mathrm{NH}_{3}$ vapours. Spraying with $\mathrm{FeCl} 3$ gave blue colour, $\mathrm{R}_{\mathrm{f}}(\mathrm{x} 100) 56$ (15\%HOAc) 30 (BAW) indicating its phenolic nature. The UV spectral data exhibited two absorption bands at ( $\lambda \max 247,375)$ characteristic for ellagic acid derivatives ${ }^{13}$. The molecular formula $\mathrm{C}_{16} \mathrm{H}_{10} \mathrm{O}_{8}$ from LC-Q/TOF - MS ${ }^{2}$ with pseudo molecular ion at $\mathrm{m} / \mathrm{z}$ : $330.97297[\mathrm{M}+\mathrm{H}]+,{ }^{1} \mathrm{H}-\mathrm{NMR}$ spectrum showed a down field singlet signal at $\delta$ ppm 7.69 (down field) integrated for two aromatic protons assigned for $\mathrm{H}-5 / 5^{\prime}$ and a singlet of six protons at $\delta$ ppm 3.98 assigned for two equivalent methoxy groups established compound 8 as 4, 4'-di$O$-methyl ellagic acid ${ }^{14}$.
Compound 9, was identified as 3, 3'-di-O-methylellagic acid 4'-O- $\alpha$-Lrhamnoside. Its ${ }^{1} \mathrm{HNMR}$ revealed presence of down field singlet signal at 7.69, and upfield singlet at 7.43 assignable for $\mathrm{H}-5{ }^{\prime}, \mathrm{H}-5$ respectively, suggested the rahmnose and $O$-methyl in position 3 ' and 4 '. The aliphatic region exhibited the singlet anomeric proton at 5.52 and asinglet methyl for rhamnosyl moiety at $1.8^{13}$. Finally, its molecular formulae was $\mathrm{C}_{22} \mathrm{H}_{20} \mathrm{O}_{12}$ from (LC-Q/TOF - MS ${ }^{2}$ ) at m/z: $477.10238[\mathrm{M}+\mathrm{H}]^{+}$for the psudo molecular ion.

Compound 10, yellow powder, molecular formula $\mathrm{C}_{17} \mathrm{H}_{12} \mathrm{O}_{8}$, LC-Q/ TOF - MS $2 \mathrm{~m} / \mathrm{z}: 344.22763[\mathrm{M}+\mathrm{H}]^{+}$, similar to 8 it exhibited the same physical and chemical properties of $8, \mathrm{R}_{\mathrm{f}}$ (x100) 60 (15\% HOAc), 29 (BAW). ${ }^{1} \mathrm{H}-\mathrm{NMR}$ spectrum showed two singlet signals at 7.59, 7.48 assigned for two aromatic protons at $\mathrm{H}^{-5}, \mathrm{H}-5$ and three non-equivalent signals at 4.01, 4.02, 3.98 for three methoxy group on the basis of the above data and by comparison with reported data, compound 10 could be identified as 3, 3', 4'-tri-O-methyl ellagic acid ${ }^{13}$.

Compounds 11, 12 showed the intrinsic chromatographic behaviour of ellagic acid derivatives and have the same physical and chemical properties of 8 . In compound 11 the two $O$-methyl groups are substituted at position 3, 3' due to the appearance of a singlet signal at 7.53(UP field) assignable for two equivalent aromatic protons (H-5/5') and a singlet of six protons at 4.00, 3.98 assignable for two methoxy groups at position 3 and 3, compound 11 is deduced to be 3, 3', di-O-methyl ellagic acid. In compound $12^{1} \mathrm{H}-\mathrm{NMR}$ spectrum showed four singlet signals at 4.08 , $4.06,4.12,3.99$ revealed four $O$-methyl in aliphatic region and one down field signal in aromatic assigned at 7.74 for $\mathrm{H}-5 / 5^{\prime}$, compound $\mathbf{1 2}$ is deduced to be 3, 3', 4, 4'-tetra-O-methyl ellagic acid ${ }^{14}$.

The gallic acid 13 and methyl gallate 14 were identified from chromatographic properties, by comparing UV spectra with reported data and by co-chromatography on TLC with authentic sample ${ }^{15,16}$.

The existence of this kind of compounds in the aerial parts of $S$. grantii was confirmed by the TPC assessment, by the Folin-Ciocalteu method and TFC. S. grantii, 258.04. $\pm 15.67 \mathrm{mg} / \mathrm{g}$ content and 380.48 $\pm 31.07 \mathrm{mg} / \mathrm{g}$ content such results confirm the significance of assessing antioxidant activity, as it depends on the structural features of organic compounds, mainly due to the presence of phenolics and flavonoids so the antioxidant properties of this species can be responsible. Analyzes of NMR revealed the presence of phenolics and flavonoids compounds in the extract of the aerial parts. Hence its ability to prevent the development of free radicals assessed.

The phenolic and flavonoid contents were $258.04 \pm 15.67 \mathrm{mg}$ GAE/G extract and $380.48 \pm 31.07 \mathrm{mg} Q E / G$ extract, respectively.

\section{BIOLOGICAL EVALUATION}

\section{In vitro Antioxidant Activity}

The antioxidant was determined by using four assays DPPH, RPC, ABTS, and FRAP.

\section{DPPH Radical Scavenging Activity}

Free radicals of (DPPH) are widely used for screening of medicinal plants to investigate their antioxidant potential. The DPPH radical scavenging activity was measured and compared with that of BHA. Results in (Figure 2) showed that DPPH radical scavenging activity of compounds (1-9) ranged from $24.83 \pm 0.32 \%$ for compound 5 (500 $\mu \mathrm{g} /$ $\mathrm{ml})$ to $88.47 \pm 0.37 \%$ for compound $2(100 \mu \mathrm{g} / \mathrm{ml})$. Compound 4 also exhibited a very high DPPH radical antioxidant activity.

\section{Reducing power capacity (RPC)}

In reducing power assay, the presence of the antioxidant agents can improvement the reduction of Fe (III)/ferric cyanide complex on the 


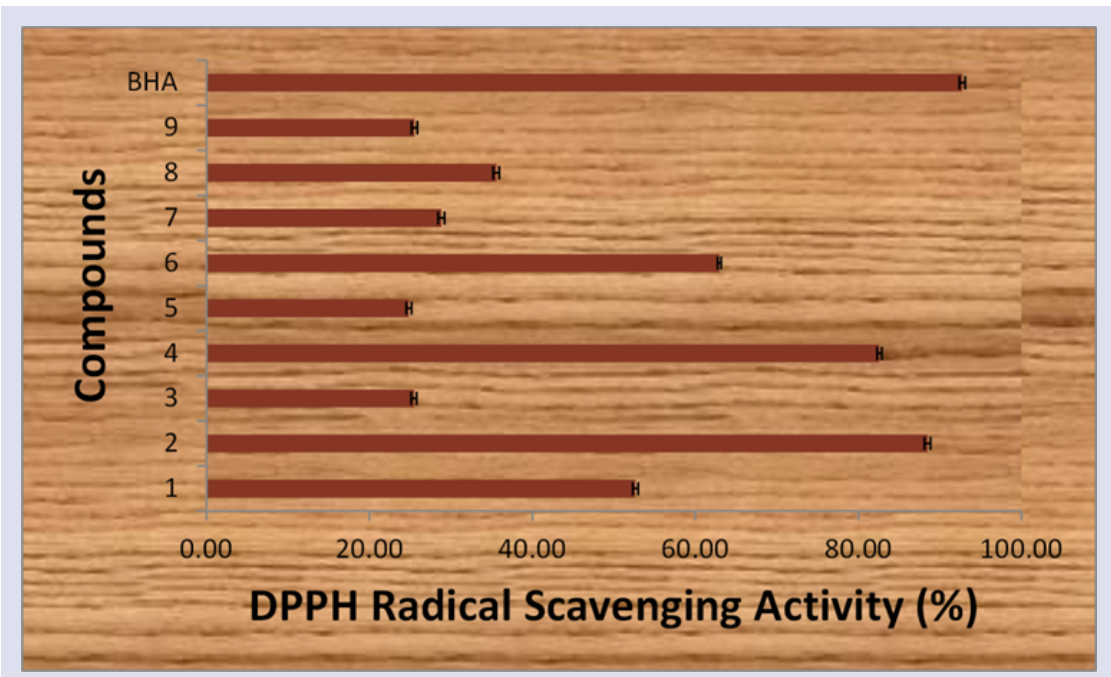

Figure 2: Radical Scavenging ability of the isolated compounds (1-9) from S. grantii on DPPH radical, (Data are means \pm standard deviation of triplicate experiments).

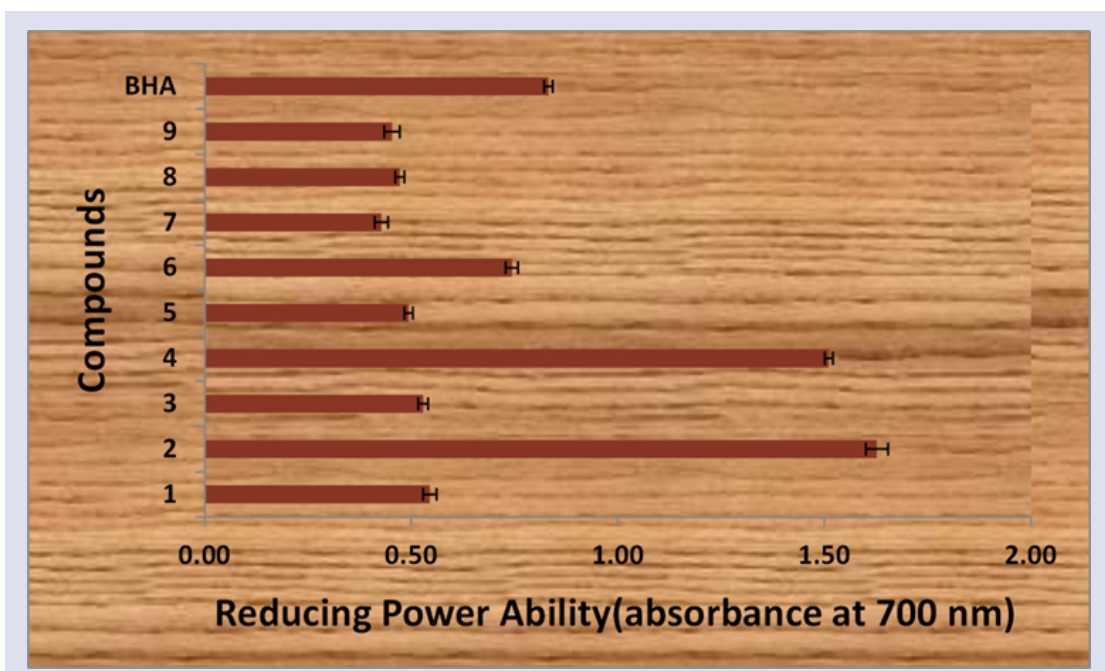

Figure 3: (RPC) of the isolated compounds (1-9) S. grantii (Data are means \pm standard deviation of triplicate experiments).

ferrous form $[\mathrm{Fe}(\mathrm{II})]$ by donating an electron. The occurrence of reluctant in the sample would cause the reduction of $(\mathrm{Fe} 3+)$ to $(\mathrm{Fe} 2+)$ ion through the donation of an electron and the creation of the Perl Prussian blue complex. Results illustrated in (Figure 3) indicated that all the examined compounds have good reducing power ability. Compounds 2, and 4 have the superiority their absorbance at $700 \mathrm{~nm}$ found to be $1.63 \pm 0.03$ and $1.51 \pm 0.01$ respectively at the concentration $500 \mu \mathrm{g} / \mathrm{ml}$. Compound 7 recorded the lowest reducing power capacity at the same concentration $(0.43 \pm 0.02)$.

\section{ABTS scavenging activity}

The isolated flavonoids and tannins as well as the synthetic antioxidant BHA revealed considerably different in their ABTS radical scavenging activities. All the isolated compounds caused an inhibition in ABTS+ activity (Figure 4). The highest ABTS scavenging activity obtained corresponded to compound $2(71.65 \pm 0.42 \%$ at the concentration 100 ug / ml), followed by compound 6 . (70.77 $\pm 0.34 \%)$ but at a higher concentration $250 \mu \mathrm{g} / \mathrm{ml}$. Also compound 4 exhibited a good ABTS radical scavenging activity $(60.89 \pm 0.18 \%)$ at a low concentration $100 \mu \mathrm{g} / \mathrm{ml}$.Compounds $\mathbf{8 ,} 9$ and 1 recorded $63.15 \pm 0.14,59.82 \pm$ 0.26 and $55.42 \pm 0.20$ respectively at the same concentration (500 $\mu \mathrm{g} / \mathrm{ml})$, while compound 5 showed the lowest activity $(31.85 \pm 0.34)$ compared to the standard BHA $(92.38 \pm 0.26$. The highest activity may be attributed to the presence of the high molecular weight flavonoids which are responsible for quenching of ABTS cation as reported by ${ }^{17}$.

\section{Ferric reducing power ability (FRAP)}

The iron reducing power test based on the reduction of Fe3+ iron to $\mathrm{Fe} 2+$ iron was used in this study to highlight the antioxidant potential of the isolated compounds (1-9). Similar trend was noticed in the obtained results of ferric reducing power ability as compound 2 exhibited the highest ferric reducing power ability, it found to be 3574 $\pm 19.14 \mu \mathrm{molTrolox} / 100 \mathrm{~g}$ DW at the concentration $100 \mathrm{ug} / \mathrm{ml}$ followed by compound 6 where the compound is achieved $3080 \pm 17.43 \mu \mathrm{mol}$ Trolox/100g DW $500 \mathrm{ug} / \mathrm{ml}$ also compounds 8, 5 and 3 recorded good ferric reducing power ability they recorded $1352 \pm 10.02,1149 \pm$ 13.50 and $1129 \pm 11.93 \mu \mathrm{mol}$ Trolox $/ 100 \mathrm{~g}$ DW respectively at the same concentration (Figure 5).

Analyzes of NMR showed that extract of aerial parts from S. Grantii has a high level of flavonoids and tannins, so its ability to inhibit free radical formation was assessed. All of the compounds tested possessed strong antioxidant activity across all assays used. Compounds 2, 


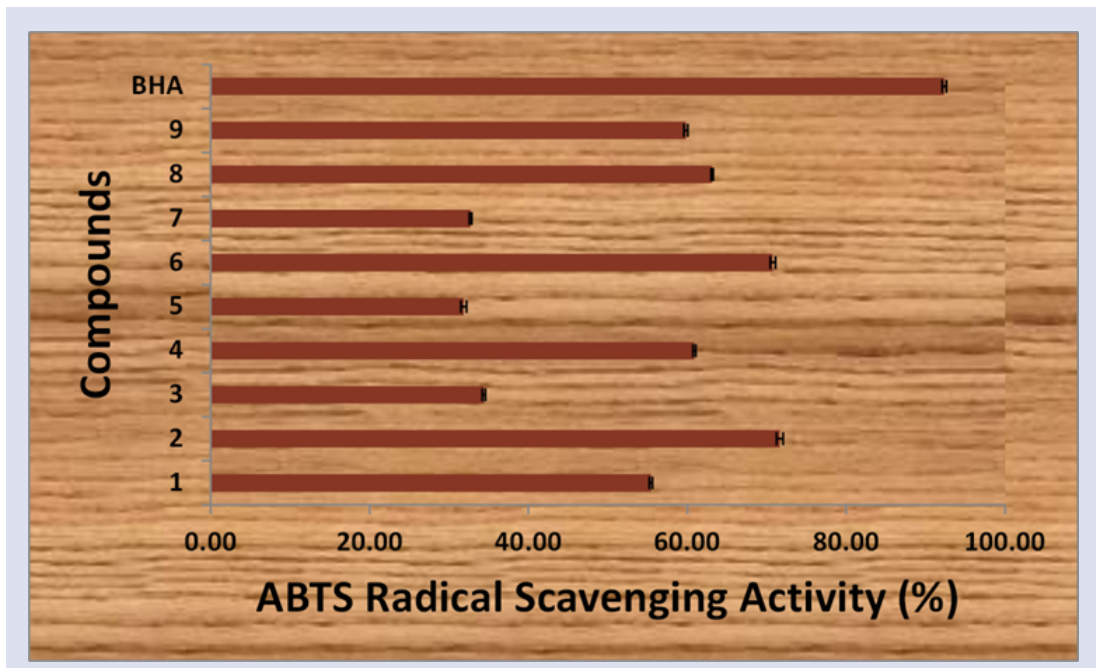

Figure 4: Scavenging ability of the isolated compounds (1-9) from S. grantii, ABTS radicals, (Data are means \pm standard deviation of triplicate experiments).

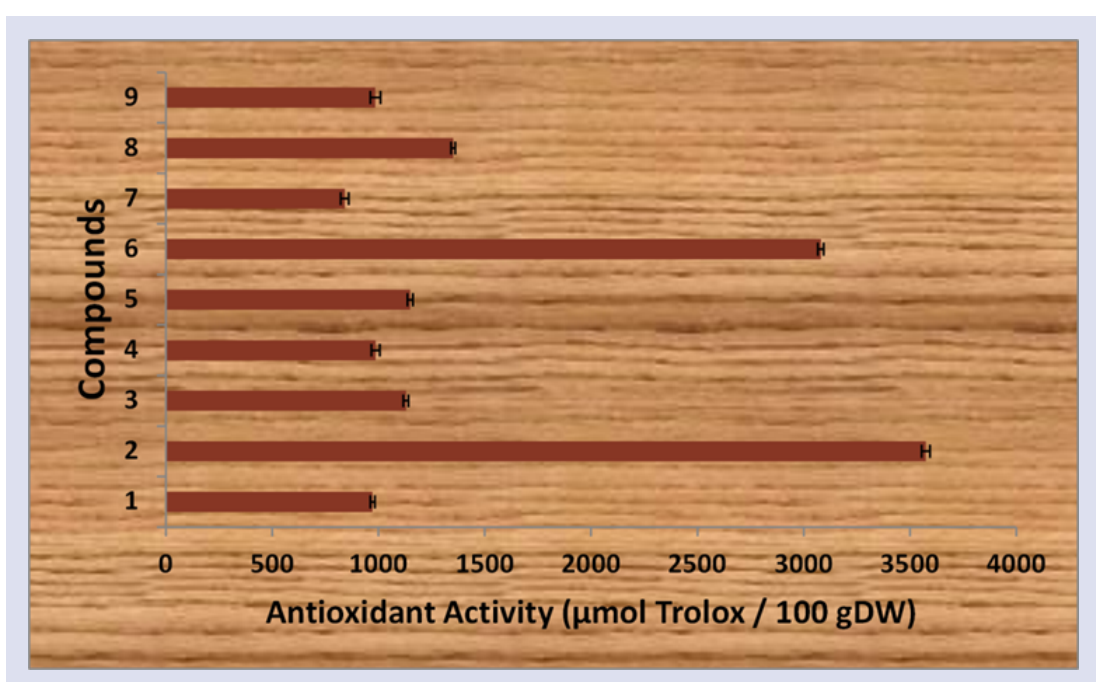

Figure 5: (FRAP) of the isolated compounds (1-9) from S. grantii (Data are means \pm standard deviation of triplicate experiments).

4 and often 6 consistently displayed higher antioxidant activity at lower concentrations than the majority of the compounds used. This high capacity can be attributed for their chemical configuration and contains multiple effective groups which were the main reason for the radical scavenging operation. Antioxidant property is widely used as a parameter for medicinal bioactive components [4]. Phenolic compounds and flavonoids may be responsible for the alcoholic extract's antioxidant properties ${ }^{18,19}$.

\section{CONCLUSIONS}

The compounds tested had strong antioxidant function as a natural source of antioxidant medicinal products.

\section{REFERENCES}

1. Yadang, Fanta, Sabine A, GermainTS, Ngatcha Z. Quantification of Bioactive Compounds and Evaluation of the Antioxidant Activity of Carissa edulisvalh (Apocynaceae) Leaves. The Scientific World Journal. 2019;1-11.

2. Azmir J, Zaidul ISM, Rahman MM, Sharif KM, Mohamed A. Techniques for extraction of bioactive compounds from plant materials: a review. J Food Eng. 2013;117:426-36.

3. Fahmy NM, Al-Sayed E, Singab AN. Genus terminalia: a phytochemical and biological review. Med Aromat Plants. 2015;4:1-21.
4. Narender P DB, Ganga R E, Sambasiva, Rao T, Mallikarjuna. Quantification of phytochemical constituents and in vitro antioxidant activity of Synadium grantii. Free Radicals and Antioxidants. 2012;2:68-72.

5. Koehn, FE, Carter GT. The evolving role of natural products in drug discovery Nat Rev Drug Discov. 2005;4:206-20.

6. Cao G, Sofic E, Prior R. Antioxidant and prooxidantbehavior of flavonoids: Structure-activity relationships. Free Radic. Biol. Med. 1997;22:749-60.

7. Costa LLG, David VC, Pinto RMC, Minozzo BR, Kozlowski. Anti-ulcer activity of Synadenium grantii látex. Braz. J Pharmacogn. 2012;22(5):1070-8.

8. Rogerio A P, Cardoso C R, Caroline F, Maria A S, Sandra R A. Glycobiolog Antiasthmatic potential of a D-galactose-binding lectin from Synadenium carinatum latex. 2007:17(8):795-804.

9. Nogueira AL, Aryane BB, Leão VMS, Benfica PL, Cunha LC. Antitumoral and antiangiogenic activity of Synadenium umbellatum Pax. Journal of Ethnopharmacology. 2008;120:474-8.

10. Borges $R$, Nascimento MVM, Carvalho AAV, Valadares MC Depaula JR. Antinociceptive and Anti inflammatory activities of the ethanolic extract from Synadenium umbellatum Pax. (Euphorbiaceae) Leaves and its fractions evidence based complementary and alternative medicine. Research Article. 2013;1-9.

11. Harborne, JB, Mabry, $\mathrm{T} J$ and Mabry H. The Flavonoids, Champan and Hall London, 1975.

12. Wardana TAP, Hidayati N, Shimizu K. An ellagic acid derivative and its antioxidant activity of chloroform extract of stem bark of syzygium polycephalum Miq. (Myrtaceae). Indones. J Chem. 2018;18(1):26-34. 
13. Guan Ye, Peng $H$, Fan M, Huang CG. Ellagic acid derivatives from the stem bark of dipentodon sinicus. Chemistry of Natural Compounds. 2007;43(2):124-7.

14. Pakulski, G, Budzianowsk J. Ellagic acid derivatives and naphthoquinones of Dionaeamuscipula from in vitro cultures, Phytochemistry. 1996;41(3):775-8.

15. Anil M, nandini P. Simultaneous isolation and identification of phytoconstituents from Terminalia chebula by preparative chromatography. Journal of Chemical Pharmacetical Research. 2010;2:97-103.

16. Anchana C, Aphiwat T, Jeremy DK Nuansri RY. Antimicrobial gallic acid from Caesalpinia mimosoides Lamk. Food Chemistry. 2007;100:1044-8.

17. Skerget M, Kotnik P, Hadolin M, Hras AR, Simonic M. Phenols, proanthocyanidins, flavones and flavonols in some plant materials and their antioxidant activities. Food Chem. 2005;89:191-8.

18. Marques THC, Melo CHS, Freitas RM. In vitro evaluation of antioxidant, anxiolytic and antidepressant-like effects of the Bellis perennis extract. Rev Bras Farmacogn. 2012;22:1044-52.

19. Gülçin I. Antioxidant properties of resveratrol: A structureactivity insight. Innov Food Sci Emerg. 2010;11:210-8.
20. Saboo S, Tapadiya, R, Khadabadi S, Deokate UA. In vitro antioxidant activity and total phenolic, flavonoid contents of the crude extracts of Pterospermumacerifolium Wild leaves (Sterculiaceae). Journal of Pharmacy Research. 2010; (3):417-23

21. Mandal B, Madan S. Preliminary phytochemical screening and evaluation of free radical scavenging activity of Stevia rebaudiana Bertoni from different geographical sources. Journal of Pharmacognosy and Phytochemistry 2013;2(1):14-9.

22. Oyaizu M. Studies on the product of browning reaction prepared from glucosamine. Jpn J. Nutrition 1986;44:307-15.

23. Re R, Pellegrini N, Proteggente A, Pannala A, Yang M. Antioxidant activity applying an improved ABTS radical cationdecolorization assay. Free Radical Biology and Medicine. 1999;26:1231-7.

24. Benzie IFF, Strain JJ. Ferric reducing, antioxidant power assay: Direct measure of total antioxidant activity of biological fluids and modified version for simultaneous measurement of total antioxidant power and ascorbic acid concentration. Methods Enzyme. 1999;299:15-27.

\section{GRAPHICAL ABSTRACT}
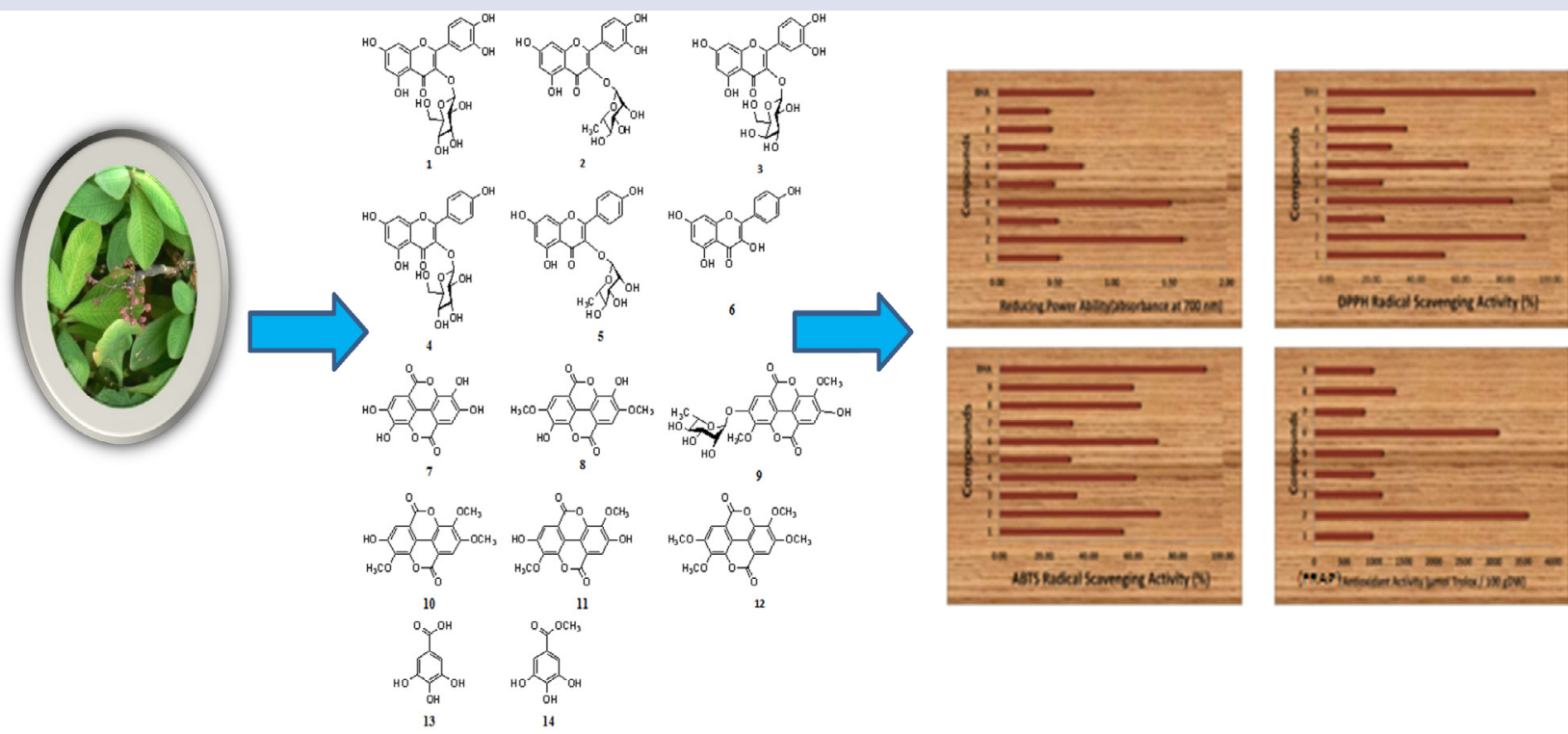

Chemical structure of isolated compounds from S. grantii and their antioxidant activity by di-erent assayes.Chemical structure of isolated compounds from S. grantii and their antioxidant activity by different assayes.

\section{ABOUT AUTHORS}

- Asmaa S. Abd Elkarim ${ }^{1 * *}$ : Researcher, ${ }^{1}$ Chemistry of Tanning Materials and Leather Technology Department, National Research Centre.

- Sahar Abdelaziz: Associate Professor, Pharmacognosy Department, Faculty of Pharmacy, Zagazig University, 44519 Zagazig, Egypt.

- Hany Gouda Attia 3,4: Department of pharmacognosy, faculty of pharmacy, Najran University, Najran 55461, Saudi Arabia. Department of pharmacognosy, faculty of pharmacy, Kafr EL- Shiekh university, Egypt.

- Prof. Hanan Anwar AlyTaie ${ }^{5:}$ Research professor of Plant Biochemistry - Plant Biochemistry Department, National Research Centre. Awarded M.SC. In Biochemistry from Cairo University in 1999 and awarded Ph.D. in Biochemistry from the same university in 2005. Reviewer in many international journals. She supervised several M. Sc. And Ph. D. Thesis.

- Rafik Monir6: Associate Professor, Pharmacognosy Department, Faculty of Pharmacy, Misr University for Science and Technology.

Cite this article: Elkarim ASA, Abdelaziz S, Attia HG, Taie HAA, Monir R. Phytochemical and Antioxidant Evaluation of the Flavonoids and Tannins from Synadenium grantii Hook f, (Ephorbiaceae). Pharmacogn J. 2020;12(6):1421-8. 